\title{
The Role of Political Stability, Labor Market and Education on Migration: The Empirical Evidence from Sri Lanka
}

\author{
T. Vinayagathasan \\ Senior Lecturer, Department of Economics and Statistics, Faculty of Arts \\ University of Peradeniya, Sri Lanka
}

Tel: 94-770-764-638Ｅ-mail: vinayagamkili@yahoo.com

Received: May 8, 2020 Accepted: June 2, 2020 Published: June 9, 2020

doi:10.5296/ber.v10i2.16988 URL: https://doi.org/10.5296/ber.v10i2.16988

\begin{abstract}
This study employs annual data from Sri Lanka over the period of 1990 - 2018 in order to investigate the impact of political instability and the existence of violence, unemployment rate, wage differential and level of education on migration. ADF unit root test confirmed that none of the variables are $\mathrm{I}(2)$, which allows us to examine the long run relationship between the variables using Autoregressive Distributed Lag (ARDL) Bound testing method. AIC is suggested to adapt ARDL (1, 0, 0, 2,0) model among the top 20 models. ARDL Bound testing approach identified the cointegrating relationship between the variables. The results of both ARDL Bound test and the ARDL version of ECM detected that unemployment rate, political instability and the existence of violence/terrorism and level of education have a positive and significant impact on net migration whereas wage differential do not have significant impact on it even though it affect the net migration negatively both in the long run and in the short run respectively. Also, the coefficients of long run results and the Wald test confirm that the impact of unemployment rate is higher than wage differential, political instability and level of education on net migration in the long run. The result of CUSUM test of selected ARDL model discloses that the estimated model is stable and this model passes the all the diagnostic test. Moreover, Granger causality test identified a causal relationship that stemming from unemployment to net migration, wage differential to net migration, political instability to net migration and level of education to net migration. These findings could be useful to policy makers when they formulating and implementing the policy related to labor markets and good governance.
\end{abstract}

Keywords: Migration, Unemployment, Wage differential, Political instability, Education, 
Bound test, Auto regressive distributive lag model

\section{Introduction}

Improving the allocation of human resources is called as migration. People living in area where they are not fully employed or partially employed are expected to move to termini that having brighter futures. However, both migration analysts and policymakers seem to have mixed views as to whether private market forces are only adequate to encourage them to do so. People living in places where they face security issues due to political instability also expected to move to destinations. Youngers are expected to change their destination for their educational purposes (under graduate and post graduate). However, migratory patterns are clearly part of the history and cultural links of a country, its political and legal framework, socio-economic characteristics, its cultural specificities and the stage in the economic cycle and economic activity.

On the one hand, there has been substantial discussion regarding policies designed to affect migration directly by permitting or tempting the unemployed to move for more hopeful labor markets. But, the implication is that the unemployed are not themselves sufficiently responsive to economic conditions. On the other hand, investment policies of in depressed places are based largely on the premise that expanded local economic chances will shrink economically forced outmigration (DaVanzo, 1978).

There are many arguments about the benefits and costs of migration for both host country and countries of origin. It is clear that immigration can be beneficial for migrants, but only if their rights are protected properly. It can also be economically beneficial for both countries of origin and host countries; however, with present economic and trading structures it is the rich and powerful countries that benefit most. Migration brings social and cultural pressures that need to be taken into account in planning for future services. Migration also has the potential for bringing peoples together culturally but friction occurs if efforts are not made to dispel the myths held by local people. It is also essential to provide good information about the local way of life to newcomers and ensure opportunities for people to mix and integrate. Where the economic preconditions exist, migration is inevitable. When people try to prevent immigration it just goes underground.

The relationship between unemployment rate and migration is not obvious. On the one hand, many studies using survey data (e.g., Fromentin, 2013; Lansing and Mueller, 1967; Saben, 1964) found that certain unemployed workers are more likely to migrate than employed workers, but, Saben, and Lansing and Mueller studies do not use ample controls for other characteristics that may have affect migration. Lansing and Mueller (1967, p. 91) further explain that people are faintly less likely to leave depressed areas than non-depressed areas. On the other hand, some of the literatures (e.g., Lowry, 1966) have obtained mixed results using aggregate data, but Lowery explain that since unemployment is often measured at the end of the period of migration and thus may have been affected by the intervening migration. Further, Lowry confirmed that outmigration to be insensitive to conditions of local labor market. Thus, the direct contribution of unemployment to migration cannot be determined (DaVanzo, 1978). 
The studies of Harris and Todaro (1970) and Todaro (1969) are considered to be founding works for the investigation of migration flows in a context of underemployment, with the presence of real wages rigidities. They explain that migrations are likely to have a negative impact on the general level of employment, since workers are encouraged to migrate to certain regions, due to higher wages, even if the rate of unemployment is higher. Some authors (e.g., Fields, 1976; Olvey, 1970; Blanco, 1964) have discussed that unemployment "push" at origin is operative but that its role is masked by improper measures of true unemployment conditions. Blanco, and Olvey suggest and employ synthetic measures such as "potential" or "prospective" rate of unemployment, which examine what unemployment rates would be if there were no out- migration (net), and find them positively correlated to (net) outmigration.

Therefore, the query of the economic impact of migration has been broadly addressed by literature of economics, notably taking into deliberation the characteristics of the migrants and the labor market of the country, the degree of substitutability and complementarity between the workers, the elasticity of work demand and supply, the mobility of workers', the protagonists' negotiating power, global demand, etc. Although if there is a quasi-consensus appears from literature of economics regarding economic impact (e.g., Longhi et al., 2010; Okkerse 2008), the conclusions can be diverge. Nevertheless, according to the context of geographical, methodological and temporal analysis, Borjas (1994) demonstrate that "the most important lesson is that the economic impact of immigration varies by time and place and can be beneficial or harmful"

In addition, several studies examine the relationship between immigration and unemployment instead of link between migration and unemployment by considering American (e.g., Ottaviano and Peri, 2012; Card, 2009; Borjas, 2003; Friedberg, 2001; Borjas, Freeman and Katz, 1997; Friedberg and Hunt, 1995; Card, 1990; Grossman, 1982) and European (e.g., Galloway and Josewocicz, 2008; Dustman, Fabbri and Preston, 2005; Gross, 2002; Winter-Ebmer and Zeimuller, 1999; Pischke and Velling 1997) countries since these countries have positive net migration. Among these studies, there is no consensus on whether the link between immigrant and wages or unemployment is negative, positive or null (e.g. Ottaviano and Peri, 2012; Card, 2009; Galloway and Josewocicz, 2008; Fabbri and Preston, 2005; Borjas, 2003). For instance, Using the data of France, Gross (2002) found some detrimental effects in the short run perspective, but in the long run, he revealed negative relationship between immigration and unemployment rate. Nevertheless, his general result shows that the inflow of immigration on the labour market indicators was not significant and temporary. Dustman, Fabbri and Preston (2005) used the data from the British Labour Force Survey aggregated into the 17 regions and have not identified any significant effects of immigration on the employment, participation and rate of unemployment. Employing the pooled cross-sections data collected from Austria, Winter-Ebmer and Zeimuller (1999) obtained only slight effect of immigration on native employees and more significant on time labour and already employed immigrants. Pischke and Velling (1997) used 328 regions data from German and concluded that no detrimental effect of the immigration on employment.

The existing evidence consistently displays that conflict affects migration on an aggregate 
level (Moore and Shellman 2004; Davenport et al. 2003; Schmeidl 1997; Weiner 1996; Zolberg et al. 1989). But, here the question is that at the individual-level, who, why and when is likely to migrate during conflict. Further, there is no empirical or theoretical action of an equally important phenomenon for non-migration during conflict.

Rios-Avila and Canavire-Bacarreza (2016) argue that "higher levels of education increases the time a worker remains unemployed, possibly by increasing the search time for a good job, as well as increases their chances of finding a job. Higher education is also related to a lower probability of leaving the labor force or migration".

When the economic environment declines, the host country population tends to fear the impact of immigration on employment or on wages (European Social Survey, 2002). For instance, following the 1974 oil crisis, European governments implemented selective or restrictive migration policy in order to slow down the entry of immigrants whose assimilation into the host country labor market was not certain and to satisfy national public opinion. Nevertheless, in Sri Lanka, from 1980s to 2009, people migrated not only for finding the job and education but also for security purposes due to unstable political environment whereas after 2009 , they migrate especially by targeting the labor markets and higher education.

Sri Lanka had experienced a prolonged internal conflict over 35 years which ended up in 2009. During this conflict, even amongst the most severe, the majority of the population has migrated internally and some certain fraction of the population migrated internationally. According to the Fig 1 (see the appendix), net migration increased during high political instability period of 1990-2001 (low rank). Nevertheless, net migration is almost stable during 2002-2006 since the country was politically stable this period due to peace agreement between Government of Sri Lanka and the Tamil fighters group called as Liberation Tigers of Tamil Eelam (LTTE). Again the conflict started in middle of 2006 and continued until middle of 2009, which may motivated the people to migrate and increased the net migration (in negative term) slightly. However, internal conflict was ended up in middle of 2009 and net migration slightly declined over the period of 2009-2015. Net migration further decreased after 2015 to yet since the country became politically more stable due to new government good governance policies implemented in 2015.

The pattern of net migration of Sri Lanka depict that political instability may have motivated the citizen to migrate internationally. However, the question is that whether the internal conflict only influenced on migration or some other factors contributed more than it? Having the mixed results regarding the relationship between unemployment and net migration based on the existing studies, an individual characteristic can be seen in the Sri Lankan economy during the last five decades. Sri Lanka experienced two-digit rate of unemployment till 1997 and then it became one digit (see Fig 2 in appendix), which implies that the rate of unemployment has gradually decreased in the last five decades while net migration gradually increased over the period of 1990-2001, almost stable since 2002-2009 and thereafter net migration decreased gradually. Therefore, we could not see the clear pattern regarding the relationship between unemployment and net migration. 
Next, data of wage rate ${ }^{1}$ in the labor markets of Sri Lanka shows a higher fluctuation over time (see Fig 3 in appendix) while pattern of migration is as explained earlier. Further, level of education rises over time (see Fig 4 in appendix) whereas pattern of migration is gradually increases till 2001, while from 2002 to 2015 is almost stable with small fluctuation and decline after 2015.

In this respect, it seems crucial to ask questions about how the labor market factors, political stability and level of education are related to migration in Sri Lanka and to wonder about the existence of cointegration and/or of a causal relationship (unidirectional or bidirectional) between migration and wage, migration and unemployment, migration and political instability and migration and level of education which of these factors highly correlated with out migration? To the best of our knowledge, there is no study that investigates the role of political instability, rate of unemployment wage and level of education on migration using Sri Lankans data. Taking this in to account, we attempt do it. In this manner also our study differs from existing literatures.

Thus, the aim of this study is to examine whether the unemployment or wage or political instability or level of education contributed more to migrate people internationally and to identify the causality relationship between these three variables and migration using data of Sri Lanka over the period of 1990-2018 with a long-term and short-term distinction, since the conclusions may diverge in particular owing to the adjustment time of the labor market and the nation's political and economic environment (Damette and Fromentin 2013, Dustmann, Glitz and Frattini 2008, Gross 2004, Cohen-Goldner and Paserman 2004).

\section{Data, Variables and Methodology}

In this study, we use annual time series data from Sri Lanka over the period of $1990-2018^{2}$ to examine the above objectives. The data of net migration (netmig) ${ }^{3}$, unemployment rate (unemp $^{4}$, wage differential (wage) ${ }^{5}$ and level of education (edui) ${ }^{6}$ were extracted from World Development Indicator of the World Bank data base and the data of political instability and the existence of violence (psav) ${ }^{7}$ was collected from World Governance Indicator data

\footnotetext{
${ }^{1}$ Remember that, we used wage differential data in our regression analysis (see the methodology section to understand how we calculated the wage differential).

${ }^{2}$ Due to the availability of the data of selected variables, we considered this period in our sample. Moreover, we ignored the income level of the household (i.e., Gross domestic product per capita) since we use wage in our model which may be able to capture it.

${ }^{3}$ The number of immigrants minus the number of emigrants over a period, divided by the person-years lived by the population of the receiving country over that period. It is expressed as net number of migrants per 1,000 populations.

${ }^{4}$ Measured as $\%$ of total labor force (national estimate)

5 Wage and salaried workers (\% of total employment) of Sri Lanka minus weighted average wage and salaried workers (\% of total employment) of U.S.A, European union countries, Middle east countries, Canada and Australia. These countries are selected based on the number migrated people.

${ }^{6}$ We used education index as proxy for level of education. We followed Asghar et al. (2012) and Vijesandiran and Vinayagathasan (2015) to calculate Education Index (EDUI), the formula is given by:
}

$$
\text { EDUI }=\left[\frac{2}{3} * \mathrm{ALI}\right]+\left[\frac{1}{3} * \mathrm{GEI}\right] \text { where, ALI }=\frac{\mathrm{ALR}-0}{100-0} \text { and GEI }=\frac{\mathrm{CGER}-0}{100-0}
$$

ALI denotes Adult Literacy Index, GEI represents Gross Enrolment Index and CGER is the Combined Gross Enrolment Rate.

${ }^{7}$ Political Stability and Absence of Violence/Terrorism measures perceptions of the likelihood of political instability and/or 
base of the World Bank.

Following the empirical literature (e.g., Fromentin, 2013; DaVanzo, 1978) in related to unemployment and migration, we developed the relationship between the variable as below:

$$
\text { netmig }_{t}=\alpha_{0}+\alpha_{1} \text { unemp }_{t}+\alpha_{2} \text { wage }_{t}+\alpha_{3} \text { psav }_{t}+\alpha_{4} \text { edui } i_{t}+\varepsilon_{\mathrm{t}}
$$

where, variables name are as explained above, $\varepsilon_{t}$ is the white noise error term and $t$ illustrate the time period.

The estimation of equation (1) begins with the identification of the order of integration of each variable using Augmented Dickey Fuller (ADF) and Philips-Perron (PP) unit root test for this analysis. Therefore, we can compare the results of ADF test with PP test to see whether we have obtained the same conclusion or not. In the second step of the estimation procedure, we have to identify the optimal lag length that can be used in the model. Because, the underlying theory and any hypothesized structure indicate to the economist that which variable to be included in the model and how many lags would be appropriate. Therefore, the method of determining the appropriate lag length is still an important issue in the time series literature since longer lag lengths increase the number of estimated parameters, reduce degrees of freedom and increase data requirements. There have been several methods proposed to deal with the problem of correctly determining the proper lag length for time series model like Vector Autoregressive (VAR), Vector Error Correction Model (VECM) and Autoregressive Distributed Lag (ARDL) etc. There are several criterions such as sequentially modified Likelihood Ratio (LR) statistics, Akaike Information Criterion (AIC), Swartz Information Criterion (SC), Hannan-Quin Information Criterion (HQIC) and Final Prediction Error (FPE) to select the optimal lag length that can be included in a time series model. However, we will adopt either one or more of these criterions in our analysis according to results and the requirements.

In the third step, we employ ARDL co-integration procedure developed by Pesaran et al. (2001) to empirically analyze the dynamic relationship between the variables described in equation (1). An ARDL representation of equation (1) is formulated as follows:

$$
\begin{gathered}
\Delta \text { netmig }_{t}=\delta_{0}+\delta_{1} \text { netmig }_{t-1}+\delta_{2} \text { unemp }_{t-1}+\delta_{3} \text { wage }_{t-1}+\delta_{4} \text { psav }_{t-1}+\delta_{5} \text { edui }_{t-1}+ \\
\sum_{i=1}^{q_{1}} \beta_{1 i} \Delta \text { netmig }_{t-i}+\sum_{i=0}^{q_{2}} \beta_{2 i} \Delta \text { unemp }_{t-i}+\sum_{i=0}^{q_{3}} \beta_{3 i} \Delta \text { wage }_{t-i}+ \\
\sum_{i=0}^{q_{4}} \beta_{4 i} \Delta \text { psav }_{t-i}+\sum_{i=0}^{q_{5}} \beta_{5 i} \Delta \text { edui }_{t-i}+e_{t}
\end{gathered}
$$

Where, $\Delta$ denotes the first difference operator, $\delta_{0}$ is the drift component, $e_{t}$ is the white noise error term, $\delta_{1} \rightarrow \delta_{5}$ : denotes the long-run coefficients, the remaining expressions with the summation sign $\left(\beta_{1 i} \rightarrow \beta_{5 i}\right)$ represent the short-run dynamics of the model.

Next we use Bound testing procedure for equation (2) to confirm the cointegrating

politically-motivated violence, including terrorism. Percentile rank indicates the country's rank among all countries covered by the aggregate indicator, with 0 corresponding to lowest rank (i.e. political instability is high), and 100 to highest rank (political instability is low). 
relationship between the variables. The Bound testing procedure is based on the F-test. The F-test is actually a test of the hypothesis of no co-integration among the variables against the existence of cointegration among the variables. This hypothesis can be tested using Wald-test (F-statistic). The asymptotic distribution of the Wald-test is non-standard under the null hypothesis of no cointegration among the variables. Two critical values are given by Pesaran et al. (2001) to check the above hypothesis. The lower critical bound assumes that all the variables are $\mathrm{I}(0)$, implying that there is no cointegrating relationship between the examined variables. The upper critical bound assumes that all the variables are I(1) which mean that there is a cointegrating relationship between the variables. Null hypothesis of no cointegration will be rejected when the computed F-statistic is greater than the upper bound critical value which concludes that variables are cointegrated. Whereas we will accept the null hypothesis when the F-statistic is below the lower bound critical value, and implying that there is no cointegrating relationship among the variables. When the computed F-statistics falls in between the lower and upper bound, then the results are inconclusive.

Once we confirmed the cointegrating relationship among the variables using above test, in the next step of the estimation procedure we obtain the short run dynamics of parameters and long run adjustment of the model by estimating the error correction version of ARDL model pertaining to the variables in equation (2) is as follows:

$$
\begin{gathered}
\Delta \text { netmig }_{t}=\pi_{0}+\sum_{i=1}^{q_{1}} \pi_{1 i} \Delta \text { netmig }_{t-i}+\sum_{i=0}^{q_{2}} \pi_{2 i} \Delta \text { unemp }_{t-i}+\sum_{i=0}^{q_{3}} \pi_{3 i} \Delta \text { wage }_{t-i}+ \\
\sum_{i=0}^{q_{4}} \pi_{4 i} \Delta \text { psav }_{t-i}+\sum_{i=0}^{q_{5}} \pi_{5 i} \Delta e d u i_{t-i}+\gamma \mathrm{ECT}_{\mathrm{t}-1}+\mu_{\mathrm{t}}
\end{gathered}
$$

where, $\gamma$ : speed of adjustment coefficient which should have statistically significant and negative sign to support the long run adjustment towards steady state line, $\mu_{\mathrm{t}}$ : pure random error term.

Wald test was adapted to test whether the impact of an additional rank of political instability is greater than the impact of an additional rate of unemployment (or wage rate or level of education) on net migration. Finally, we adapted Vector Error Correction Model (VECM) based granger causality approach to identify the direction of causality between unemployment rate, wage differential, political instability, education index and net migration.

\section{Results and Discussions}

First we examined the equation (1) by ordinary least squared (OLS) technique and results are given below in Table 1. 
Table 1. Results of OLS Method

\begin{tabular}{|l|l|l|}
\hline Variable & Coefficient & Probability value \\
\hline UNEMP & $0.37083^{* * *}$ & 0.000 \\
\hline WAGE & -0.03065 & 0.581 \\
\hline PSAV & $0.02047^{*}$ & 0.082 \\
\hline EDUI & $0.00075^{*}$ & 0.069 \\
\hline C & -6.95948 & 0.031 \\
\hline
\end{tabular}

R-squared $=0.951, \operatorname{Prob}($ F-statistic $)=0.000$

Note: $* * * * * *$ represents variables are statistically significant at $1 \%, 5 \%$ and $10 \%$ level of significance respectively.

The above results reveal that unemployment rate (at 5\% level of significance), education index and political instability and the existence of violence/terrorism (at 10\% level of significance) have a positive and statistically significant impact on net migration. The relationship between unemployment rate and net migration is as expected to the Sri Lankas' experience, since emigrants are higher than the immigrant, and some of the existing studies (e.g., Fromentin, 2013; Lansing and Mueller, 1967; Saben, 1964). This results indicates that an increase in unemployment rate by 1 per cent tend to increase emigrants by $0.523 / 100$ unit higher than the immigrant. As expected and some of the existing empirical studies (e.g., Moore and Shellman, 2004; Davenport et al., 2003; Schmeidl, 1997; Weiner, 1996) an increase in political instability tends to increase emigrants by $0.02047 / 100$ unit higher than the immigrant. Also a rise in level of education tends to increase the out migration. The domestic labor market may not support to educated people to find good job with sufficient wage or political situation of the country may motivated them to migrate internationally or many of them emigrate by the purpose of higher/ post graduate education and not back to their home country. This could be the reason that we found positive association between education index and net migration. In contrast wage does not have statistically significant impact on net migration. This implies that wage do not play a major role on migration than the other variables. Since most of the macroeconomic indicators may have time dependent movement without de-trending, estimating the model by OLS may produce the spurious results. Thus, we checked the order of integration of each series and employed ARDL bound testing approach in this regard to compare the consistency of the relationship between the variables.

Both ADF and PP unit root test approaches confirm that all variables became stationary at their first difference form except wage which became stationary in level form when we included intercept only in the model. Although we obtained the same results when we included both trend and intercept in the model but the series of political instability became non-stationary under PP unit root test approach. Thus, ADF and PP unit root test approaches with intercept only in the model confirm the presence of $\mathrm{I}(0)$ and $\mathrm{I}(1)$ variables (see Table 2 below). Therefore, we adopt ARDL bound testing method to estimate the parameter. 
Table 2. Results of ADF and PP Unit Root Test

\begin{tabular}{|l|l|l|l|l|l|}
\hline \multirow{2}{*}{ Form } & Variables & \multicolumn{2}{|l|}{ ADF } & PP \\
\cline { 3 - 6 } & & Intercept & Trend \& Intercept & Intercept & Trend \& Intercept \\
\hline \multirow{4}{*}{ Level } & NETMIG & 0.071 & 0.927 & 0.113 & 0.972 \\
\cline { 2 - 6 } & UNEMP & 0.057 & 0.901 & 0.059 & 0.899 \\
\cline { 2 - 6 } & EDUI & 0.999 & 0.468 & 0.996 & 0.995 \\
\cline { 2 - 6 } & WAGE & $0.041 * *$ & $0.004 * * *$ & $0.025 * *$ & $0.004 * * *$ \\
\cline { 2 - 6 } & PSAV & 0.648 & 0.175 & 0.857 & 0.606 \\
\hline $1^{\text {st }}$ Difference & NETMIG & $0.004 * * *$ & $0.000 * * *$ & $0.003 * * *$ & $0.000 * * *$ \\
\cline { 2 - 6 } & UNEMP & $0.001 * * *$ & $0.001 * * *$ & $0.001 * *$ & $0.001 * * *$ \\
\cline { 2 - 6 } & EDUI & $0.010 * *$ & $0.019 * *$ & $0.008 * * *$ & $0.016 * *$ \\
\cline { 2 - 6 } & WAGE & $0.000 * *$ & $0.009 * *$ & $0.000 * * *$ & $0.000 * * *$ \\
\cline { 2 - 6 } & PSAV & $0.004 * * *$ & $0.019 * *$ & $0.028 * *$ & 0.114 \\
\hline
\end{tabular}

Note: Probability values are given in the Table. ***, **, * represents variables are stationary at $1 \%, 5 \%$ and $10 \%$ level of significance respectively.

The result of AIC for model selection is given below:

Akaike Information Criteria (top 20 models)

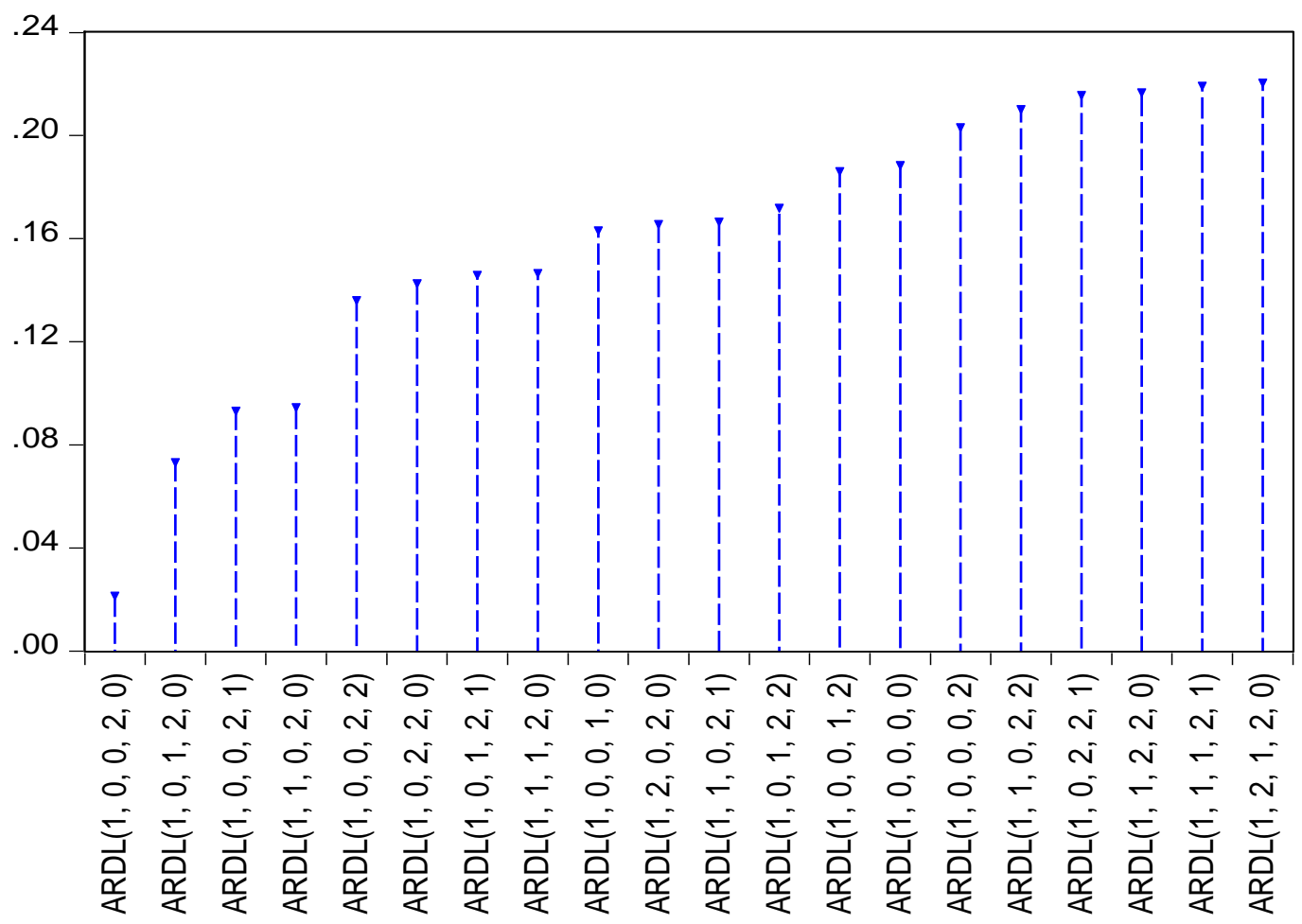

Figure 1. Results of Optimum Lag Length of Each Variable (AIC)

Based on the unrestricted VAR model and AIC criteria, we employed 2 lags as optimum lag 
for the model and we applied this lag length to again AIC to select the optimum number of lag for each variables that can be included in the model (ordering of the variables are netmig, unemp, wage, psav, edui). Since the lowest value is better, the results suggest that to employ ARDL $(1,0,0,2,0)$ model among the top 20 models in order to estimate the parameters. The Figure 2 below represents the stability of the selected model.

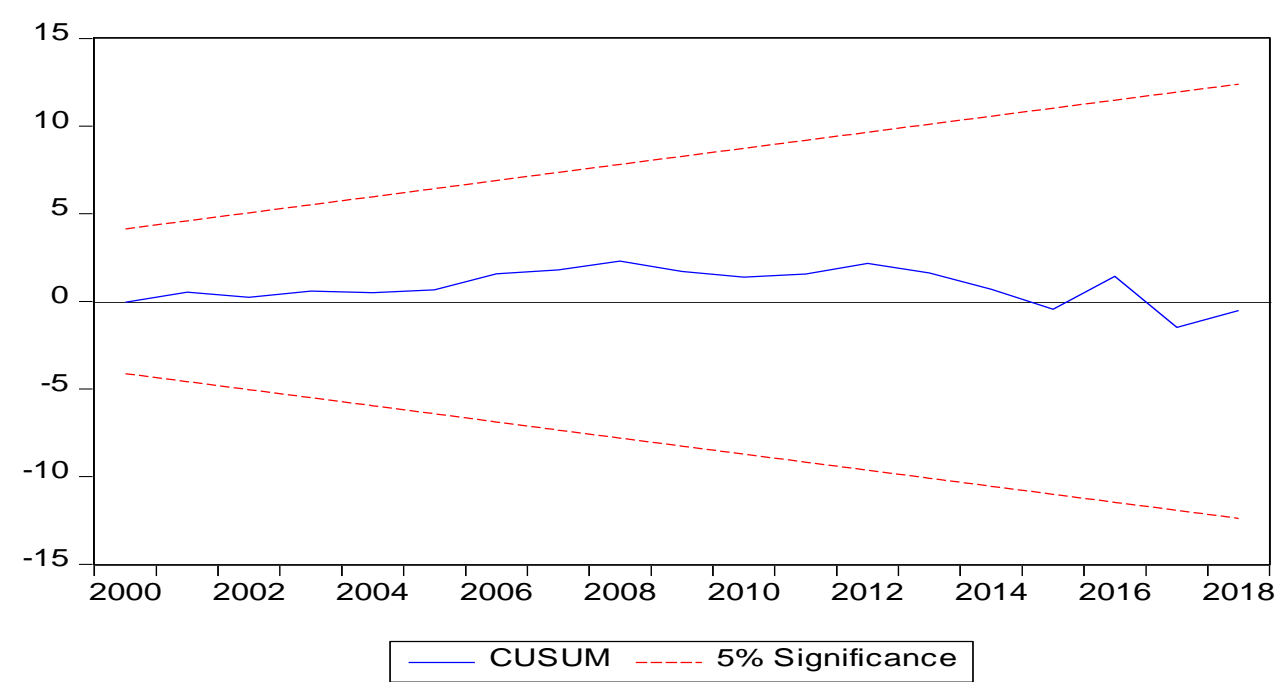

Figure 2. The Results of CUSUM Test for ARDL $(1,0,0,2,0)$ model

The CUSUM test plot lies between the lower and upper critical bounds at the 5\% level of significance, which confirms the stability of the selected model.

The ARDL (1, 0, 0, 2, 0) model passed all the diagnostics tests (see Table 3). That is, firstly, Lagrange Multiplier (LM) test of serial correlation advocates that the residuals are not serially correlated since we failed to reject the null hypothesis of no serial correlation in the residual as probability value is greater than the $5 \%$ level of significance. Second, according to the Jarque-Bera (JB) test, the null hypothesis of normally distributed residuals cannot be rejected as probability value is higher than $5 \%$ significance level, which indicates that error is normally distributed. Thirdly, Breusch-Pagan-Godfrey (BPG) test of heteroscedasticity suggests that the disturbance term in the equation is homoscedastic as we failed to reject the null hypothesis since the probability value exceed the 5\% significance level. Finally, the Ramsey RESET test result confirms that there is no specification error in the estimated model since we accept the null hypothesis of no omitted variable in the model as probability value is greater than $5 \%$ level of significance. 


\section{Macrothink}

Table 3. The Results of Diagnostics Test of ARDL $(1,0,0,2,0)$

\begin{tabular}{|l|l|}
\hline Test & Probability value (F or Chi-square) \\
\hline Serial Correlation [LM Test: $\left.\chi_{(\mathrm{df})}^{2}\right]$ & 0.602 \\
\hline Normality Test (Jarque-Bera) & 0.970 \\
\hline Heteroscedasticity (BPG Test) & $0.053^{*}$ \\
\hline Omitted Variable (Ramsey's RESET) & $0.083^{*}$ \\
\hline
\end{tabular}

Note: Probability values are given in the Table. $* * *, * * *$ represents variables are stationary at $1 \%, 5 \%$ and $10 \%$ level of significance respectively.

Next we examine whether there exist cointegrating relationship between variables by adopting the ARDL Bound testing procedure. The result of Wald test confirms that there exist cointegrating relationship between the variables under considered in this study since we reject the null hypothesis of no cointegration among the variables due to the computed F-statistics (3.867) is greater than the upper bound critical value (3.49) at 5\% level of significance (see Table 4 below).

Table 4. The Results of ARDL Bounds Test

\begin{tabular}{|l|l|l|l|l|}
\hline \multicolumn{2}{|l|}{ F-Bounds Test } & \multicolumn{3}{l|}{ Null Hypothesis: No level relationship } \\
\hline Test Statistics & Value & Significant level & I(0) & I(1) \\
\hline F-statistic & 3.867287 & $10 \%$ & 2.2 & 3.09 \\
\hline k & 4 & $5 \%$ & 2.56 & 3.49 \\
\hline & & $1 \%$ & 3.29 & 4.37 \\
\hline
\end{tabular}

Since we identified the cointegrating relationship between the variable, now we estimate the model further in order to find the long run relationship between the variables, which are given in the Table 5 below:

Table 5. The Results of ARDL Long run Form (Dependent Variable: net migration)

\begin{tabular}{|l|l|}
\hline Variables & Coefficients \\
\hline unemp & $0.539(0.000)^{* * *}$ \\
\hline Wage & $-0.000072(0.998)$ \\
\hline psav & $0.0051(0.049)^{* *}$ \\
\hline edui & $0.0271(0.000)^{* * *}$ \\
\hline c & $-10.667(0.000)$ \\
\hline
\end{tabular}

Note: Probability values are given in the parenthesis. $* * *, * *, *$ represents the variables are statistically significant at $1 \%, 5 \%$ and $10 \%$ level of significance respectively. 
The above results reveals that unemployment rate, political instability and the existence of violence/ terrorism and education index have a positive and statistically significant impact on net migration in the long-run while wage differential do not affect net migration significantly even though it affect the net migration negatively. When looking at the indicators of the local labor market conditions, as it is expected, living in a nation with higher unemployment rates and/or law wage tends to increase out migration than the inward migration. Some of the existing studies (e.g., Fromentin, 2013; Lansing and Mueller, 1967; Saben, 1964) and Sri Lanka experiences also supports these findings. That is, Sri Lanka's data of immigration and emigration shows that the net migration (that is, immigrants minus emigrants) is negative and it increases continuously. The people living in area where they are facing difficulties to find the job and/or low wage rate are expected to move the destination that having brighter futures. Also unstable political situation of the country until middle of 2009 could be another reasons for emigrants are higher than immigrants in Sri Lanka. Our estimated results of political instability and the existence of violence/ terrorism (psav) also supporting to this argument since we find the positive association between netmig and psav, which suggest that when the country could not maintain the stable political situation which tend to increase the emigrants in a certain level that increases the net migration in absolute term. Even though civil war ended up in middle of 2009 and country able to maintain stable political situation in a certain level, data of net migration of Sri Lanka depict a slight increment after 2009 to till. Increase in skilled labor emigrants and country failure to attend the reconsolidation of war affected people could be the reasons for it. Moreover, wage differential does not have significant impact on net migration in the long run even though which has theoretically expected sign. This suggest that as long as if citizens are able to find job opportunity locally and if the country is functioning smoothly without any violence people like to stay in the country and would like work at any wage rate. Further, an increase in level of education tends to increase the out migration in the long run. The reason for finding this positive link between these two indictors might be as i explained under OLS estimation.

Finally we estimated the error correction representation of ARDL model in order to identify the short run dynamic relationship and long run adjustment between the variables. The results are given below: 
Table 6. Results of Error Correction Representation of ARDL Model

\begin{tabular}{|l|l|l|l|}
\hline Dependent Variable: $\Delta$ NETMIG \\
\hline \multirow{2}{*}{ Variables } & Lag order & 1 & 2 \\
\cline { 2 - 4 } & 0 & $0.1308(0.521)$ & \\
\hline$\Delta$ NETMIG & & & \\
\hline$\Delta$ UNEMP & $0.2143(2.710)^{* *}$ & & \\
\hline$\Delta$ WAGE & $0.0131(0.476)$ & & \\
\hline$\Delta$ PSAV & $0.0148(1.832)^{*}$ & $0.0384(4.918) * * *$ & $-0.0249(-2.225) * *$ \\
\hline$\Delta$ EDUI & $0.0291(2.181) * *$ & & \\
\hline ECT $(-1)$ & $-0.159(-3.538)^{* * *}$ & \\
\hline $\mathrm{R}^{2}$ & 0.843 & & \\
\hline F - Stat & 8.065 &
\end{tabular}

Note: Test statistics are given in the parenthesis. $* * *, * * *$ represents the variables are statistically significant at $1 \%, 5 \%$ and $10 \%$ level of significance respectively.

Above results revels that unemployment, political instability and the existence of violence/ terrorism (current and one year lagged value) and education index have a statistically significant and positive impact on net migration whereas wage differential do not affect the net migration significantly in the short run. We also found the same conclusion in the long run. Therefore the reasons for these relationships might be as we explained earlier. Further, coefficient of error correction term (ECT) is significant and negative which implies that the net migration move backward toward steady state line with the speed of $15.9 \%$ in each year one period after the exogenous shocks.

The coefficients of long run results and the Wald test confirm that the impact of unemployment $^{8}$ is more than wage differential ${ }^{9}$, political instability and the existence of violence/terrorism ${ }^{10}$ and education index on net migration both in the long run and in the short run. Moreover, unemployment affects the net migration largely in the long run (0.539) than the short run $(0.2143)$ whereas wage and political instability affect the net migration largely in the short run than the long run. If there is a political instability and violence or terrorist activities in the country it will takes time to solve this issues. Therefore, in the short run publics are expected to migrate largely, however when the government take necessary action to solve this problem then we can reduce migration in certain level in the long run. This could be the reason that we found short run impact of PSAV on net migration is higher than the long run impact. If the wage is low in the labor markets, labors are expected to change their destination immediately in order to meet their day to day expenditure. However, if the labor union or other relevant unions involve in this problem and fight against the lower wage which will increase the wage in the future which may prevent the labor to change their

\footnotetext{
8 The effect of $1 \%$ increase in unemployment on net migration is 0.2143 in the short run and 0.539 in the long run.

9 Although wage does not have statistically significant impact on net migration the effect of $1 \%$ increase in wage rate on net migration is 0.0131 in the short run and 0.000072 in the long run.

${ }_{10}$ The effect of 1rank increase in political instability on net migration is 0.0148 in the short run and 0.0051 in the long run.
} 
destination. This could be the reason that we found short run impact of wage on net migration is higher than the long run impact. Furtherer, level of education affects the net migration largely in the short run (0.0291) than the long run (0.0271). The people who displaced initially for higher education purposes may have returned in the long run largely once their education is completed. This could be reason that we found long run impact is less than the short run impact.

Finally we discuss the direction of causality between the variables via error correction representation of ARDL model. The results are presented below:

Table 7. The Results of Granger Causality Test

\begin{tabular}{|c|c|c|c|}
\hline Null Hypothesis & & Probability Value & Decision \\
\hline Unemployment & $\rightarrow$ Net migration & 0.034 & Rejected \\
\hline Wage & $\rightarrow$ Net migration & 0.013 & Rejected \\
\hline PSAV & $\rightarrow$ Net migration & 0.001 & Rejected \\
\hline EDUI & $\rightarrow$ Net migration & 0.027 & Rejected \\
\hline
\end{tabular}

The results reveal that unemployment, political instability, wage differential and education index cause net migration. That is we found a causality relationship between unemployment and net migration, wage differential and net migration, political instability and the existence of violence and net migration and education index and net migration in the long run. This implies that citizens' are very much concern about labor market conditions and safety life in the host country which may push them to migrate.

\section{Conclusion and Policy Recommendations}

The aim of this study is to examine the role of political instability, unemployment, wage differential and education index on migration. We employed annual data of Sri Lanka over the period of $1990-2018$ in order to achieve above objective. ADF and PP unit root test approaches confirmed that none of the variables are $I(2)$, whereas wage is $I(0)$ and other all variables including dependent variable are I(1) which allows us to examine long run relationship between the variables using ARDL Bound testing method. AIC suggested to employing ARDL $(1,0,0,2,0)$ model among the top 20 models in order to estimate the parameters. The result of CUSUM test of selected ARDL model discloses that the estimated model is stable. And test of serial correlation, heteroscedasticity, omitted variable and normality of the error term do not identify any of these issues in the selected model. ARDL Bound testing approach identified the cointegrating relationship between the variables which confirm the existence of long run relationship among the variables considered in this study. The results of both ARDL bound test and the ARDL version of ECM detected that as expected to theory and some of the existing studies (e.g., Fromentin, 2013; Lansing and Mueller, 1967; Saben, 1964) unemployment rate, education index and political instability and the existence of violence/terrorism have a positive and statistically significant impact on net migration whereas wage do not have significant impact on it even though it affect the net migration negatively in the long run and in the short run respectively. The coefficients of long 
run results and the Wald test confirm that the impact of unemployment is more than wage differential, level of education and political instability and the existence of violence/terrorism on net migration in the long run. Moreover, unemployment affects the net migration largely in the long run (0.539) than the short run (0.2143) whereas wage differential, education index and political instability affect the net migration largely in the short run than the long run. Moreover, Granger causality test identified a unidirectional causal relationship that stemming from unemployment to net migration, wage differential to net migration, education index to net migration and political instability to net migration in the long run .

This findings indicates that in order to limit the out migration, in the long run perspective, government of Sri Lanka need to addresses issues related unemployment whereas in the short run, has to be considered to increase the wage rate of the labor force and increase the quality of the education and the education system. In addition to this, both in the short run and in the long run country should be in the peace full situation politically and violently in order to control the out migration. Since the effect of unemployment on emigration is higher than the wage differential or political instability in the long run, the government of Sri Lanka should take necessary action to reduce the rate unemployment by providing relevant job for youth and should implement restrictive or selective migration policy in order to prevent the emigration of skilled people. Hence, policy makers need to consider these findings when they formulating and implementing the policy related to labor markets.

\section{Conflict of interest}

The author declares no potential conflict of interest.

\section{Acknowledgements}

I am grateful to two anonymous referees, for their valuable comments and suggestions. All errors in this study are my own.

\section{References}

Blanco, C. (1964). Prospective unemployment and interstate population movements. The review of economics and statistics, 221-222. https://doi.org/10.2307/1928188

Borjas, G. J. (2003). The labor demand curve is downward sloping: reexamining the impact of immigration on the labor market. Quarterly Journal of Economics, 118(4), 1335-1374. https://doi.org/10.1162/003355303322552810

Borjas, G. J. (1994). The economics of immigration. Journal of economic literature, 32(4), 1667-1717. https://www.jstor.org/stable/2728791

Borjas, G. J., Freeman, R. B., Katz, L. F., DiNardo, J., \& Abowd, J. M. (1997). How much do immigration and trade affect labor market outcomes? Brookings papers on economic activity, 1997(1), 1-90. https://doi.org/10.2307/2534701

Card, D. (1990). The impact of the Mariel boatlift on the Miami labor market. Industrial and Labor Relations Review, 43(2), 245-257. https://doi.org/10.1177\%2F001979399004300205 


\section{Macrothink}

Business and Economic Research ISSN 2162-4860 2020, Vol. 10, No. 2

Card, D. (2005). Is the new immigration really so bad?. The economic journal, 115(507), F300-F323. https://doi.org/10.1111/j.1468-0297.2005.01037.x

Card, D. (2009). Immigration and inequality. American Economic Review, 99(2), 1-21. https://doi.org/10.1257/aer.99.2.1

Cohen-Goldner, S., \& Paserman, M. D. (2011). The dynamic impact of immigration on natives' labor market outcomes: Evidence from Israel. European Economic Review, 55(8), 1027-1045. https://doi.org/10.1016/j.euroecorev.2011.05.002

Damette, O., \& Fromentin, V. (2013). Migration and labour markets in OECD countries: a panel cointegration approach. Applied Economics, 45(16), 2295-2304.

https://doi.org/10.1080/00036846.2012.661400

DaVanzo, J. (1978). Does unemployment affect migration? Evidence from micro data. The Review of Economics and Statistics, 60(4), 504-514. http://doi.org/10.2307/1924242

Davenport, C., Moore, W., \& Poe, S. (2003). Sometimes you just have to leave: Domestic threats and forced migration, 1964-1989. International Interactions, 29(1), 27-55.

https://doi.org/10.1080/03050620304597

Dustmann, C., Fabbri, F., \& Preston, I. (2005). The impact of immigration on the British labour market. The Economic Journal, 115(507), F324-F341.

https://doi.org/10.1111/j.1468-0297.2005.01038.x

Dustmann, C., Glitz, A., \& Frattini, T. (2008). The labour market impact of immigration. Oxford Review of Economic Policy, 24(3), 477-494.

https://doi.org/10.1093/oxrep/grn024

Fields, G. S. (1976). Labor force migration, unemployment and job turnover. The Review of Economics and Statistics, 58, 407-415. http://doi.org/10.2307/1935872

Friedberg, R. M. (2001). The impact of mass migration on the Israeli labor market. The Quarterly Journal of Economics, 116(4), 1373-1408.

https://doi.org/10.1162/003355301753265606

Friedberg, R. M., \& Hunt, J. (1995). The impact of immigrants on host country wages, employment and growth. Journal of Economic perspectives, 9(2), 23-44.

http://doi.org/10.1257/jep.9.2.23

Fromentin, V. (2013). The relationship between immigration and unemployment: The case of France. Economic Analysis and Policy, 43(1), 51-66.

https://doi.org/10.1016/S0313-5926(13)50003-8

Galloway, R. M., \& Jozefowicz, J. J. (2008). The effects of immigration on regional unemployment rates in the Netherlands. International Advances in Economic Research, 14(3), 291-302. https://doi.org/10.1007/s11294-008-9157-8

Gross, D. M. (2004). Impact of immigrant workers on a regional labour market. Applied Economics Letters, 11(7), 405-408. https://doi.org/10.1080/1350485042000248950 


\section{Macrothink

Gross, D. M. (2002). Three million foreigners, three million unemployed? Immigration flows and the labour market in France. Applied Economics, 34(16), 1969-1983.

https://doi.org/10.1080/00036840110111095

Grossman, J. B. (1982). The substitutability of natives and immigrants in production. The review of economics and statistics, 64(4), 596-603. http://doi.org/10.2307/1923944

Harris, J. R., \& Todaro, M. P. (1970). Migration, unemployment and development: a two-sector analysis. The American economic review, 60(1), 126-142.

Lansing, J., \& Mueller, E. (1967). The geographic mobility of labor. [Online] Available: http://hdl.handle.net/2027/mdp.39015071812551

Longhi, S., Nijkamp, P., \& Poot, J. (2010). Joint impacts of immigration on wages and employment: review and meta-analysis. Journal of Geographical Systems, 12(4), 355-387. https://doi.org/10.1007/s10109-010-0111-y

Lowry, I. S. (1966). Migration and Metropolitan Growth: Two Analytical Models. Chandler, San Francisco, CA. https://trove.nla.gov.au/version/12423944

Moore, W. H., \& Shellman, S. M. (2004). Fear of persecution: Forced migration, 1952-1995. Journal of Conflict Resolution, 48(5), 723-745.

https://doi.org/10.1177\%2F0022002704267767

Okkerse, L. (2008). How to measure labour market effects of immigration: A review. Journal of Economic Surveys, 22(1), 1-30. https://doi.org/10.1111/j.1467-6419.2007.00533.x

Olvey, L. D. (1972). Regional growth and interregional migration-Their pattern of interaction. Review of Regional Studies, 2(2), 139-163. [Online] Available:

https://rrs.scholasticahq.com/article/10622-regional-growth-and-interregional-migration-their -pattern-of-interaction

Ottaviano, G. I., \& Peri, G. (2012). Rethinking the effect of immigration on wages. Journal of the European economic association, 10(1), 152-197.

https://doi.org/10.1111/j.1542-4774.2011.01052.x

Peri, G., \& Sparber, C. (2009). Task specialization, immigration, and wages. American Economic Journal: Applied Economics, 1(3), 135-69. http://doi.org/10.1257/app.1.3.135

Pischke, J. S., \& Velling, J. (1997). Employment effects of immigration to Germany: an analysis based on local labor markets. Review of Economics and Statistics, 79(4), 594-604.

https://doi.org/10.1162/003465397557178

Rios-Avila, F., \& Canavire-Bacarreza, G. J. (2016). Unemployed, now what? The effect of immigration on unemployment transitions of native-born workers in the United States. Center for Research in Economics and Finance (CIEF), Working Papers, (16-25).

https://dx.doi.org/10.2139/ssrn.2827120

Saben, S. (1964). Geographic mobility and employment status, March 1962-March 1963. Monthly Lab. Rev., 87(8), 873-881. [Online] Available: 


\section{Macrothink}

Business and Economic Research ISSN 2162-4860 2020, Vol. 10, No. 2

https://heinonline.org/HOL/LandingPage?handle=hein.journals/month87\&div=99\&id=\&pag $=$

Schmeidl, S. (1997). Exploring the causes of forced migration: A pooled time-series analysis, 1971-1990. Social Science Quarterly, 284-308. https://www.jstor.org/stable/42864338

Todaro, M. P. (1969). A model of labor migration and urban unemployment in less developed countries. The American economic review, 59(1), 138-148.

https://www.jstor.org/stable/1811100

Weiner, M. (1996). Bad neighbors, bad neighborhoods: An inquiry into the causes of refugee flows. International Security, 21(1), 5-42. https://doi.org/10.1162/isec.21.1.5

Winter-Ebmer, R., \& Zweimüller, J. (1999). Do immigrants displace young native workers: the Austrian experience. Journal of Population Economics, 12(2), 327-340.

https://doi.org/10.1007/s001480050102

Zolberg, A. R., Suhrke, A., \& Aguayo, S. (1989). Escape from violence: Conflict and the refugee crisis in the developing world. Oxford University Press on Demand.

\section{Appendix}

Appendix 1.

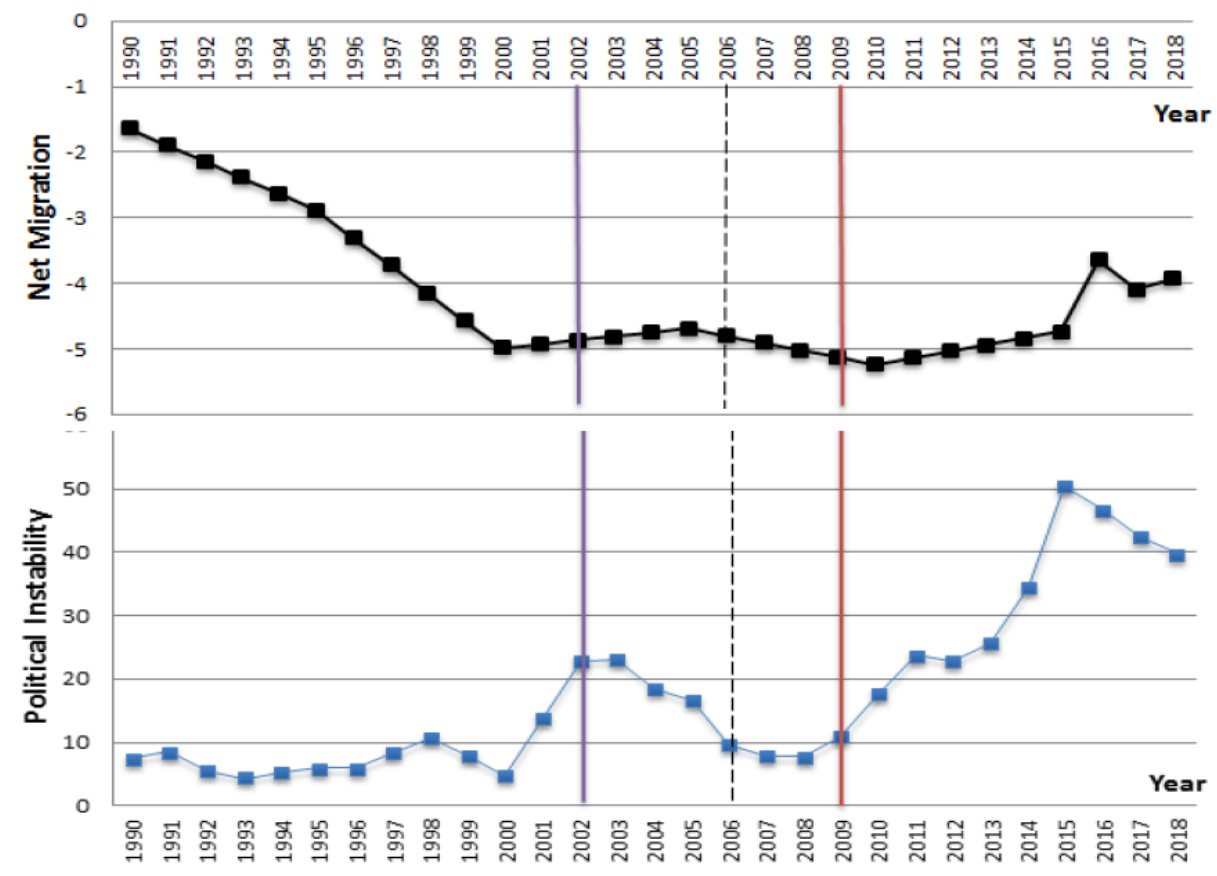

Figure 1. Pattern of Net Migration and Political Stability \& Absence of Violence (1990-2018)

Source: Authors' Calculation Based on Central Bank of Sri Lanka Data 


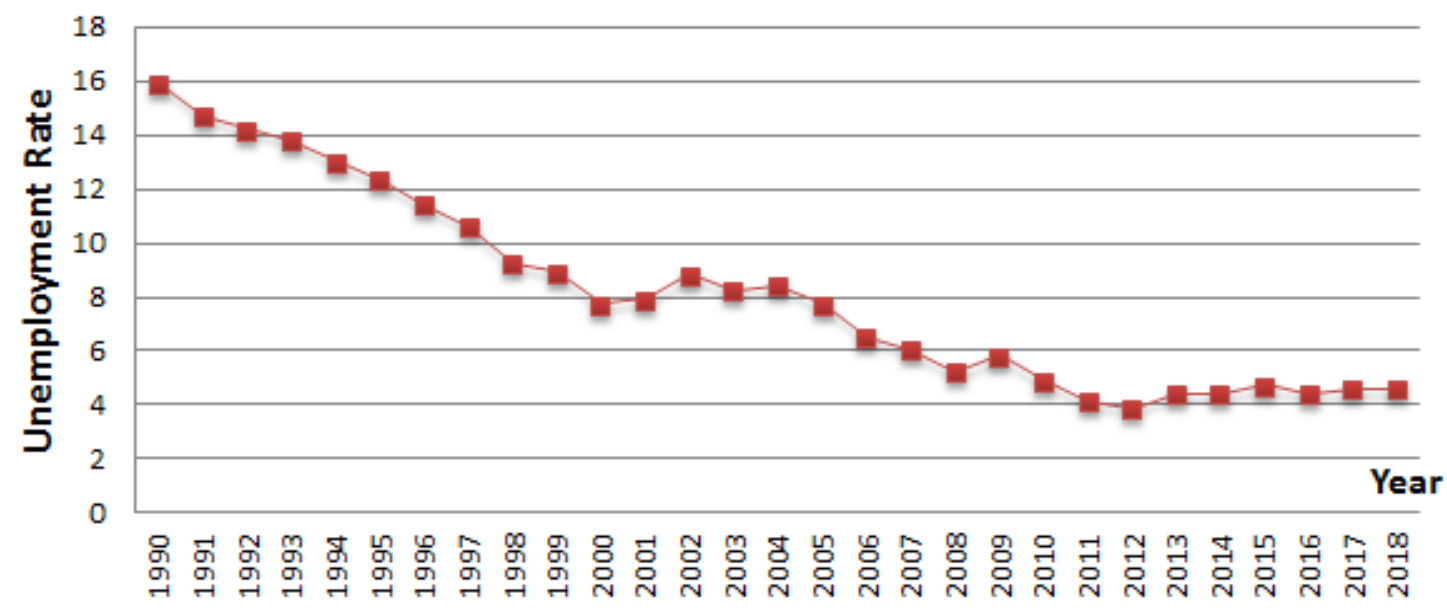

Figure 2. Pattern of Unemployment rate in Sri Lanka (1990-2018)

Source: Authors' Calculation Based on Central Bank of Sri Lanka Data.

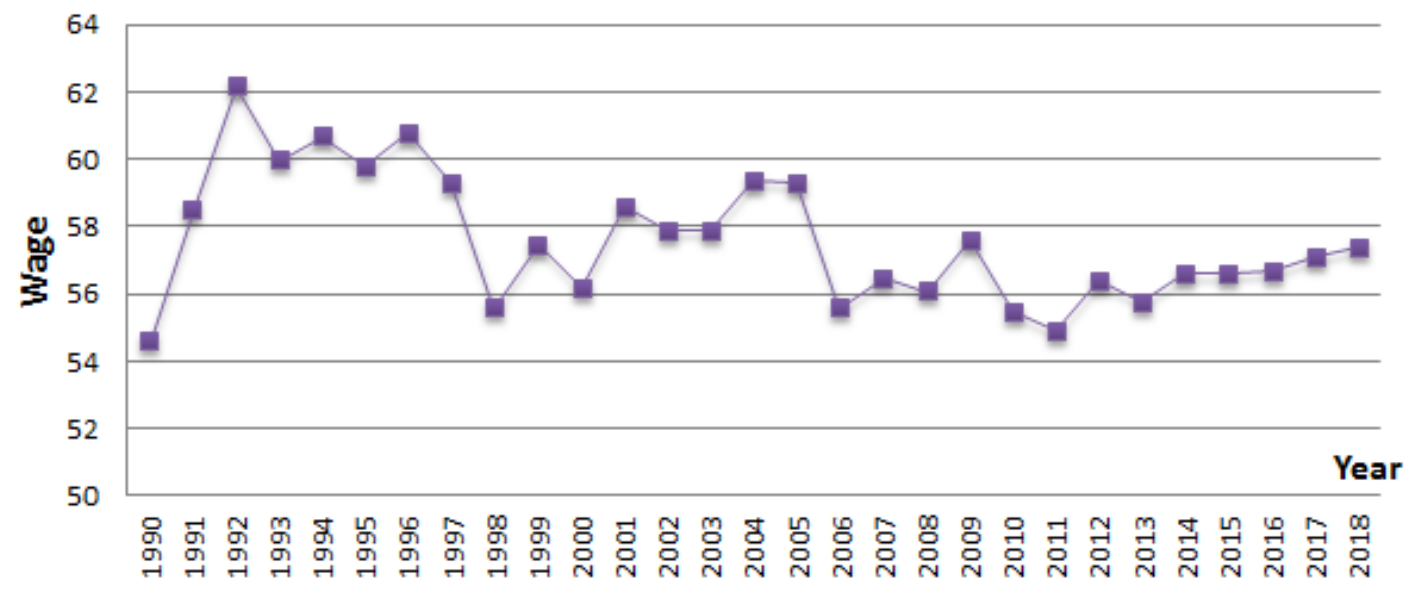

Figure 3. Pattern of Wage in Sri Lanka (1990-2018)

Source: Authors' Calculation Based on Central Bank of Sri Lanka Data 


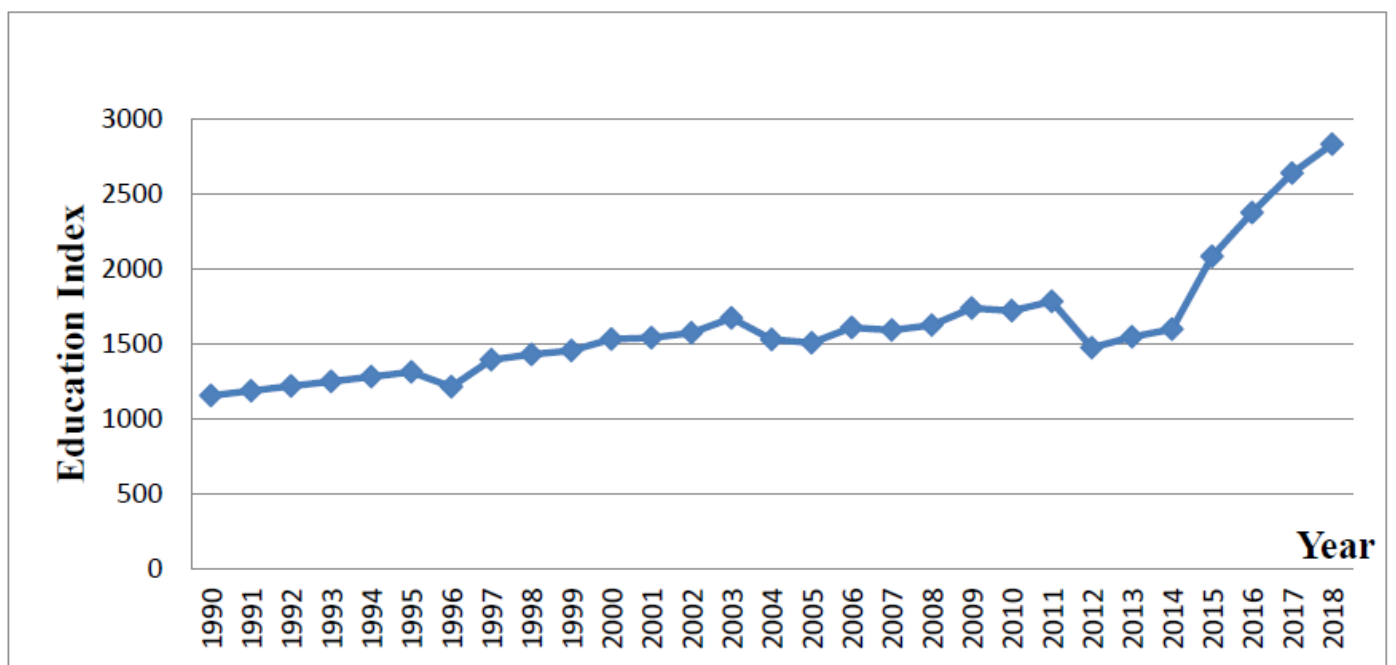

Figure 4. Pattern of Education Index in Sri Lanka (1990-2018).

Source: Authors' Calculation Based on Central Bank of Sri Lanka Data

\section{Copyright Disclaimer}

Copyright for this article is retained by the author(s), with first publication rights granted to the journal.

This is an open-access article distributed under the terms and conditions of the Creative Commons Attribution license (http://creativecommons.org/licenses/by/4.0/). 